\title{
Variation of Morphological, Quantity and Quality of essential oil in Vetiveria zizanioides (L.) Nash grown under three fertilizer conditions
}

By

Arampath Mudiyanselage Champika Hiroshini Wijesooriya

Thesis submitted to the University of Sri Jayewardenepura in partial fulfillment requirement for the award of the Master of Science in Industrial Utilization of Medicinal and Aromatic Plants. 


\section{DECLARATION}

The work described in this thesis was carried out by me under the supervision of Prof.A.M. Abeysekera (The Dean,The faculty of Applied Sciences, University of Sri Jayewardenepura), Prof. S.I. Samarasinghe (The Head, Department of Chemistry, University of Sri Jayewardenepura) and Mrs. Sudeepa Sugathadasa (Scientist (Pharmacognosy), BMARI) and a report on this thesis has not been submitted in whole or in part to any university or any other institution for another Degree.

$0.08: 2010$

Date
..A:M.C.H:Wijesooriya

Signature of the candidate 
"I/ We certify that the above statement made by the candidate is true and that this thesis is suitable for submission of the university for the purpose of evaluation."

Prof. A. M. Abeysekera

The Dean

The faculty of Applied Sciences

University of Sri Jayewardenepura

Gangodavila

Nugegoda

Sri Lanka
Prof. S. I. Samarasinghe

The Head

Department of Chemistry

University of Sri Jayewardenepura

Gangodavila

Nugegoda

Sri Lanka

\footnotetext{
Sorther $2917 / 2010$

Mrs. Sudeepa Sugathadasa

Scientist (Pharmacognosy)

BMARI

Nawinna

Maharagama

Sri Lanka
} 


\section{TABLE OF CONTENTS}

Page No

Table of contents I

List of Table $\quad$ IV

List of Figures $\quad$ V

Acknowledgement $\quad$ VI

Abstract

$\begin{array}{lll}\text { CHAPTER } 1 \text { INTRODUCTION } & 1\end{array}$

1.1 Classification of the plant 1

1.1.1 Habitat and Distribution 2

1.1.2 Cultivation \& Post harvesting $\quad 2$

1.1.3 Vetiver as Eco-friendly grass 3

1.1.4 Medicinal Value $\quad 4$

1.1.5 Multiple Uses of Vetiver 5

1.1.6 Commercial Applications of Vetiver 5

1.1.7 Chemical composition 6

$\begin{array}{ll}\text { 1.2 Description of the project } & 10\end{array}$

CHAPTER 2 MATERIALS AND METHODS 11

2.1 Land preparation $\quad 11$

2.1.1 Treatment levels $\quad 12$

2.1.2 Fertilizer application and irrigation $\quad 12$ 
2.1.3 Field Layout at Girandurukotte

2.1.4 Field planting

2.1.5 Harvesting

14

2.1.6 Drying

14

2.2 Macroscopic studies on roots Materials $\quad 15$

$\begin{array}{ll}2.3 \text { Studies on Organoleptic Character } & 15\end{array}$

2.3.1 Identification of Color $\quad 15$

$\begin{array}{ll}\text { 2.3.2 Identification of Odor } & 15\end{array}$

2.3.3 Identification of Taste 16

2.3.4 Identification of Texture 16

$\begin{array}{ll}\text { 2.4. Studies on Microscopic characters of roots } & 17\end{array}$

$\begin{array}{ll}\text { 2.4.1 Anatomical studies } & 17\end{array}$

$\begin{array}{ll}\text { 2.4.2 Powder studies } & 18\end{array}$

$\begin{array}{ll}\text { 2.5. Physiochemical Analysis } & 19\end{array}$

$\begin{array}{ll}\text { 2.5.1 Determination of Total ash } & 19\end{array}$

2.5.2 Determination of Acid insoluble ash $\quad 20$

2.5.3 Determination of Water soluble ash $\quad 21$

2.5.4 Determination of Alcohol soluble extractive 22

2.5.5 Determination of Water soluble extractive 23

$\begin{array}{ll}2.6 \text { Chemical Analysis } & 24\end{array}$

2.7 Analysis of quality of Vertiver oil using GC 25 
$\begin{array}{ll}3.1 \text { Macroscopic characters } & 26\end{array}$

$\begin{array}{ll}3.2 \text { Organoleptic Characters } & 27\end{array}$

$\begin{array}{ll}3.3 \text { Microscopic Characters } & 28\end{array}$

3.3.1 Structure of Vetiver root 28

3.3.1.2 Comparison of Epidermal Layer 32

3.3.1.3 Comparison of XylemVessels in vascular tissue 32

3.3.2 Powder studies of Vertiver roots 34

3.4 Physicochemical Analysis (purity Test) 35

$\begin{array}{ll}3.5 \text { Chemical Analysis } & 36\end{array}$

3.5.1 Vetiver oil obtained by steam distillation 36

3.5.2 Yield of the oil 36

3.6 Analysis of the quality of Vertiver oil using GC 39

3.6.1 Solvent peak (Dichloromethane) 39

3.4.6.2 Identified Peaks for Control Samples $\quad 40$

3.6.3 Identified Peaks for Inorganic
Fertilizer Treated Samples;

3.6.4 Identified Peaks for Organic
Fertilizer Treated Samples

3.6.5 Table $18 \quad 46$

$\begin{array}{ll}3.5 .6 \text { Table } 19 & 47\end{array}$

$\begin{array}{ll}3.5 .7 \text { Table } 20 & 48\end{array}$

3.5.8 Table $21 \quad 49$

$\begin{array}{ll}3.5 .9 \text { Table } 22 & 50\end{array}$ 
CHAPTER- 5 REFERENCES 53

$\begin{array}{ll}\text { APPENDIX 1 } & 55\end{array}$

$\begin{array}{ll}\text { APPENDIX } 2 & \mathbf{5 7}\end{array}$

List of Tables

Page No

Table 1: Different fertilizer levels $\quad 12$

Table 2: Field Layout $\quad 13$

Table 3: Macroscopic Characters ( Vertiver roots) 26

Table 4: Organoleptic Characters of Vetiver roots in three different treatments 27

Table 5: Number of cell layers presence in epidermis 32

Table 6: Mean number of xylem vessels in roots of three different treatments $\quad 32$

Table 7: Physicochemical Analysis (purity Test) 35

Table 8: Yield of oil \% in Different Fertilizer Treated Samples 36

Table 9: Peak dimensions for Sample -1(Control) 40

Table 10: Peak dimensions for Sample-2 40

Table 11: Peak dimensions for sample-3 41

Table 12: Peak dimensions for sample -1(Inorganic) 42

Table 13: Peak dimensions for sample - 2 42

Table 14: Peak dimensions for Sample - 3

Table 15: Peak dimensions for Sample -1(Organic) 44

Table 16: Peak dimensions sample - 2 44

Table 17: Peak dimensions for sample -3 45

Table 18: No1 Peak Area Vs Type of Fertilizer Treated Samples 46 
Table 19: No-2 Peak Area Vs Type of Fertilizer Treated Samples 47

Table 20: No-3 Peak Area Vs Type of Fertilizer Treated Samples 48

Table 21: No-4- Peak Area Vs Different Fertilizer Treated Samples 49

Table 22: Peak Areas Vs Type of Fertilizer Treated Samples 50

\section{List of Figures}

Fig 1: Vetiver plants in the field

Fig 2: Field ready to plant 01

Fig 3: One month after planting 11

Fig 4: TS of Vetiveria zizanioide (L) Nash root (10x 40) 13

Fig 5: Epidermal Cells (10x40) 28

Fig 6: Sclerenchynatous Cells (10x40) 29

Fig 7: Starch grains $(10 \times 40)$ 29

Fig 8: Yellowish oil globules $(10 \times 40)$ 30

Fig 9: Nut shape cell with Air Space (10x40) 30

Fig 10: Some diagnostic characters of root powder $(10 \times 40)$ 31

Fig 11: Fiber and pitted vessels in root powder $(10 \times 40)$ 34

Fig 12: $5 \mathrm{ml}$ volumetric flask containing extracted Vetiver oil 34

Fig 13: Yield of oil \% Vs Type of Fertilizer 36

Fig 14: Solvent Peaks 37

Fig 15: Main Peaks identified 39

Fig 16: Peaks identified for Sample -1 (Control) 39

Fig 17: Peaks identified for sample -2 40

Fig 18: Peaks identified sample -3 40

Fig 19: Peaks identified for sample -1 (Inorganic) 41

Fig 20: Peaks identified for sample -2 42 
Fig 21: Peaks identified for sample -3

Fig 22: Peaks identified for Sample -1(Organic) 44

Figure 23: Peaks identified for sample -2 44

Figure 24: Peaks identified for sample -3 45

Figure 25: No-1- Peak Area Vs Type of Fertilizer Treated Samples 46

Figure 26: No-2 Peak Area Vs Type of Fertilizer Treated Samples $\quad 47$

Figure 27: No-3 Peak Area Vs Type of Fertilizer Treated Samples 48

Figure 28: No-4 - Peak Area Vs Different Fertilizer Treated Samples 49

Figure 29: Peak Area Vs Type of Fertilizer Treated Samples 50 


\section{ACKNOWLEDGEMENT}

First and foremost I wish to express my deepest gratitude to my supervisor, Prof. A.M. Abeysekera, Dean, Faculty of Applied Science, University of Sri Jayawardenapura for his valuable advices and guidance given throughout this study and for sparing his valuable time in bringing this study to successful completion.

Then I wish to extend my since gratitude to my supervisor Prof S.I. Samarasinghe, Head, Department of Chemistry, University of Sri Jayawardenapura for her kind advices, encouragement and guidance given me throughout the period of this study.

I am also grateful to my supervisor, Mrs. Sudeepa Sugathadasa,Scientist (Pharmacognosy), BMARI, Nawinna, Maharagama, for the encouragement, kind support and valuable advices and guidance given me during the period of research project and also approved me leave and supported during the entire studying period.

My special thanks will go to Mr. R.Gunawardene (Commissioner, Department of Ayurveda) and Dr ( Mrs) D. Senasekara, Director of BMARI, Nawinna, Maharagama for directing and guiding me for this M.Sc Course.

I extend my sincere thanks to Dr Chinthaka and all academic staff and non-academic staff of the Department of Chemistry and my colleagues who are working with me at BMARI, for giving me their kind support and assistance in various ways.

Finally, I owe a special word of thanks to my Parents and my family members who shared the stress \& tension with me and the encouragement given me throughout the study. 


\title{
Variation of Morphological, Quantity and Quality of essential oil in Vetiveria zizanioides (L.) Nash grown under three fertilizer conditions.
}

\section{A.M.C.H.Wijesooriya}

\begin{abstract}
Vetiveria zizanioides (L.) Nash is a perennial grass belongs to family Poaceae which is called as Savendara in Sinhala and Vetiver in English. This plant occurs in India, Sri Lanka, Burma , Malaya and topical Africa. In Sri Lanka, it is found in the warmer part of the island. Roots are the main part of this plant and roots are used for medicinal preparations in the treatment of typhoid fever, haemoptysi, anaemia, skin and blood disease, uninary disorders, pile, oedema, pneumonia, meningitis, burn, snakebite and scorpion sting, tonic for weakness.
\end{abstract}

Vetiver can be grown in any type of soil. This plant well known as an eco friendly tool to prevent the soil erosion. Value of the plant increases with its multiple uses of the dried roots are used in manufacturing different handicrafts , scenting clothes, protected clothes from moths and make useful ingredient in insect repellents.

Commercially important essential oil known as Vetiver oil is extracted by steam distillation from the roots. This oil is one of the most valuable and important raw material in perfumery and has extensive applications in the soap and cosmetic industries. Vetiver oil is extremely 
complex, it contains sesquiterpene-type compounds and their derivatives. Vetivone , khusimol can be considered as the marker compounds of Vetiver oil.

Application of fertilizer effect (three fertilizer treatments such as Organic, Inorganic and without fertilizer (Control)) on morphological characters, oil yield and quality of the roots were observed in this study. Roots treated with Inorganic fertilizer contained more branching than the other two. Oil was extracted using a simultaneous steam distillation and solvent extraction method. The yield of the oil in Organic, Control and, Inorganic fertilizer treated plant roots gave $0.69 \%, 0.35 \%, 0.08 \%$ respectively. Quality of Vetiver oil in each samples were identified using Gas Chromatography (GC) method and high quality was observed in samples treated with Organic fertilizer. 


\section{CHAPTER 1}

\section{INTRODUCTION}

Vetiveria zizanioides (L.) Nash is a perennial grass belongs to family POACEAE. This plant is called as Savendara in Sinhala, Ushira in Sanskrit and Khus khus grass or Vetiver in English. It is a perennial herb with a branched, densely tufted root stock with long spongy, aromatic root fibers. Stems $60-70 \mathrm{~cm}$ high, stout, erect, leafy, solid, smooth and polished. Leaves $30-60 \mathrm{~cm}$ long, $0.8-1.8 \mathrm{~cm}$ broad. Spikelet's are grey to purplish, 4-6 $\mathrm{mm}$ long, in pairs, one sessile the other pedicelled; 2-flowered; the lower floret is reduced to a lemma, upper bisexual in sessile, male in pedicelled spikelets, glumes are armed with stout tubercle based spines, lemmas awnless. There are two types of Vetiver grass are recorded one growing in wild and the other being cultivated (1).

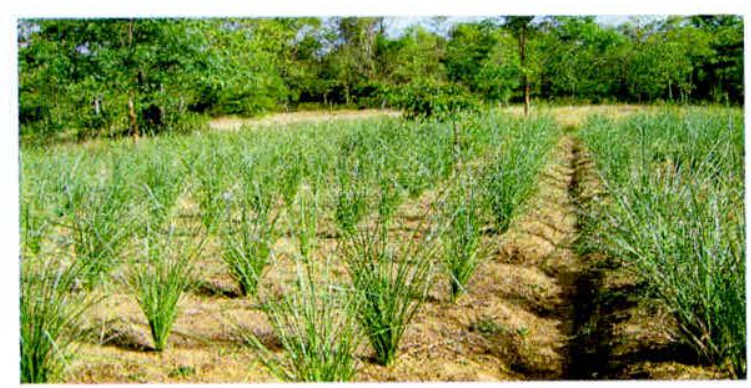

Fig 1 : Vetiver plants in the field

\subsection{Classification of the plant}

Vetiver is belongs to Kingdom Plantae and further divided into division Magnoliophyta. This plant is belongs to class Liliopsida and order Poales. This is the member of family Poaecae. According to its botanical name plant is categorized under the genus Vetiveria and species zizanioides. (Synonyms: Andropogen zizanioid) 


\subsubsection{Habitat and dstribution}

This plant occurs in India, Sri Lanka, Burma, Malaya and Topical Africa. It is cultivated in the Philippines and India. In Sri Lanka, it is found in the warmer part of the island on margins of tanks. Plants collected from Rampaikkulem, Polonnaruwa, Ritigala, Batticaloa, Dambulla and Colombo (2).

\subsubsection{Cultivation and post harvesting}

Vetiver grows in any type of soil but rich and fairly well drained loam is consider best, the loam soils $(\mathrm{pH} \mathrm{6-8)}$ which are loose in texture are ideal for roots growth and harvesting as well (4). Warm and damp weather condition necessary for optimum growth. The Vetiver plant required long day conditions and plenty of sunlight for better growth.

Full grown root clump about $15-20 \mathrm{~cm}$ are the main propagation part of this plant. Before planted Vetiver field should be free of perennial weeds and shrubs. Roots are the parts of official interest, so fertilizer like Farm Yard Manure (FYM), Phosphorus $\left(\mathrm{P}_{2} \mathrm{O}_{5}\right)$, Pottasium $\left(\mathrm{K}_{2} \mathrm{O}\right)$ and Nitrogen help in better root yield of this plant (3). Harvesting is recommended in between 15-18 months to get fully developed root system and high yield of oil. Harvesting earlier than 15 months after planting, the immature roots yield oil of poor quality with green earthy odor (1). 
Properly developed somewhat thicker roots, yield an oil of better quality and its optical rotation and specific gravity are higher, the odor fuller, richer more lasting. Oil derived from older roots are usually of darker color than the oil distilled from the younger roots. If the roots stay in ground for over two years, the yield of oil diminishes considerably as the root system tend to become woody and lose in essential oil content and the oil become very viscous with a dark color but of high quality (1). Vetiver oil can obtained using wild as well as cultivated Vetiver roots.

\subsubsection{Vetiver as Eco-friendly grass}

This plant well known as an eco friendly tool to prevent the soil erosion and it is mostly practiced in the up country tea growing areas of Sri Lanka. Roots of this plant serving as an underground barrier, the roots hold the soil together, retain water, as well as filter and absorb plant nutrient (nitrogen and phosphorous) and hazardous chemical substances such as aluminum, manganese, arsenic, cadmium, chromium, nickel, copper, mercury, lead, zinc and it could be applied to purify water, and thus to help in wastewater treatments (4).

Vetiver is also planted around the base of fruit and perennial trees on the plains, and on dry, deteriorated area in order to preserve rainwater in the soil. Vetiver leaves are also used for mulching to maintain soil moisture. It will grow in all types of soil regardless of fertility, $\mathrm{pH}$ or salinity. It has been considered widely for conservation of soil against erosion of topsoil in various parts of the world. E.g. introduce in many volcanic islands and mountainous slopes against excessive erosion during the topical rains as a soil 